\title{
Physiological properties of new species of Acidithiobacillus isolated from abandoned Tin mine in Ha Thuong, Thai Nguyen province
}

\author{
Một số đặc điểm sinh lý của vi khuẩn Acidithiobacillus spp. phân lập được tù mỏ \\ thiếc bỏ hoang ở Hà Thương, tỉnh Thái Nguyên
}

Research article

Nguyen, Tuyet Anh ${ }^{1}$; Nguyen, Thi Thuy Tuyen ${ }^{1}$; Duong, Thi Thuy ${ }^{1}$; Le, Thi Phuong Quynh ${ }^{2}$; Ho, Cuong $\mathrm{Tu}^{1} *$

${ }^{1}$ Institute of Environmental Technology, A30 bld., 18 Hoang Quoc Viet, Cau Giay, Hanoi, VIETNAM; ${ }^{2}$ Institute of Natural Product Chemistry, Vietnam Academy of Science and Technology, 18 Hoang Quoc Viet, Cau Giay, Hanoi, Vietnam

\begin{abstract}
Acidophilic bacteria are able to tolerate acidic environment and also contribute to the lowering of environmental $\mathrm{pH}$ value, implying potential applications in metal-leaching technology extracting metals from tailings and electronic wastes. In this study, we conducted a sampling campaign in abandoned Tin mine in Ha Thuong, Thai Nguyen province, to isolate acidophilic bacteria and to study physiological characteristics of the isolated bacteria. As a result, two acidophilic bacteria were successfully isolated and identification by $16 \mathrm{~S}$ rDNA gene sequences showed that the two bacteria are similar to Acidithiobacillus ferrooxidans and Acidithiobacillus thiooxidans (98\% and $94 \%$ of similarity, respectively). Both strains are tolerant of $\mathrm{pH}$ in the range of 3 and have the ability to grow optimally at temperatures of $30^{\circ} \mathrm{C}$.
\end{abstract}

Vi khuẩn ua axit có ý nghĩa ứng dụng trong công nghệ tách rút kim loại tù quặng đuôi và ngay cả tù̀ rác thải linh kiện điện tử. Trong nghiên cứu này, chúng tôi đã tiến hành thu mẫu ở mỏ thiếc bỏ hoang ở Hà Thượng, Thái Nguyên nhằm phân lập được nhóm vi khuẩn ua axit và qua đó nghiên cứu một số đặc điểm sinh lý của vi khuẩn này. Kết quả chúng tôi đã phân lập được hai chủng vi khuẩn va axit. Định dạng bằng nhận diện trình tụ gen $16 \mathrm{~S}$ rADN cho thấy hai vi khuẩn này có độ tuoong đồng là $98 \%$ với vi khuẩn Acidithiobacillus ferrooxidans và $94 \%$ Acidithiobacillus thiooxidans. Cả hai chủng vi khuẩn đều có tính chịu pH trong khoảng 3 và có khả năng sinh trưởng tối ưu ở nhiệt độ $30^{\circ} \mathrm{C}$.

Keywords: Acidithiobacillus, acid mining drainage, bioleaching, morderate temperature tolerance

\section{Introduction}

The disposal of mining waste (such as tailing, waste rocks, slugs, mill, etc.) is a major environmental problem nowadays. Mining waste consists of many heavy metals ( $\mathrm{Au}, \mathrm{Zn}$, $\mathrm{Cd}, \mathrm{Hg}, \mathrm{As}, \mathrm{Co}$, etc.) what are most frequent grounds of hydrometallurgical waste changed into hazardous waste. In recent years, the bioleaching of heavy metals has been more and more interested in because of its application to mining waste and electronic waste (Willner et al., 2013)(Wang et al., 2009)(Sugio et al., 2008)

In the bioleaching process, microorganisms reduce the $\mathrm{pH}$ value of the environment and dissolve solid compound containing metals. The process was applied to recover the metals from mining waste or electronic waste. Due to the microbial flexibility, microorganisms adapt easily to changing and extreme living conditions of the process (Willner et al., 2013). It's environmental friendly, cheaper and easier to control than conventional techniques.

Acidophilic microorganisms are key players in the bioleaching techniques, because of its ability to utilize both $\mathrm{Fe}^{2+}$ and sulfur moieties in sulfide ores as energy source (Rzhepishevska et al., 2007)(Sharma et al., 2012). They include four groups of following bacteria: Acidithiobacillus ferrooxidans, Acidithiobacillus thiooxidans, Acidithiobacillus albertensis, Acidithiobacillus caldus (Willner, 
2012). Acidithiobacillus ferrooxidans and Acidithiobacillus thiooxidans are the well-studied representatives of all. These bacteria were usually found in both natural and artificial environments such as the mining area of metal ores. The groups are a Gram-negative, $\gamma$-proteobacterium, rodshape, motile by flagella. Relevant grow temperature for them is $30^{\circ} \mathrm{C}$ and $\mathrm{pH}$ is less than four, however, it can't be lower than one (Sharma et al., 2012). All groups are autotrophic species which utilize inorganic compounds as energy sources. For example, Acidithiobacillus thiooxidans and Acidithiobacillus ferroxidans can oxidize inorganic sulphur compounds as sole energy substrate to grow both aerobically and anaerobically (Rzhepishevska, 2008). And Acidithiobacillus ferroxidans is the only group that can also oxidize $\mathrm{Fe}^{2+}$.

Recent studies usually use a thiosulfate and a polysulfide as electron donors to increase the bioleaching of metal sulfides. The ore of metal sulfides is first degraded by chemical attack of $\mathrm{Fe}^{3+}$ and/or protons. Thiosulfate is the main intermediate degraded the disulfides pyrite $\left(\mathrm{FeS}_{2}\right)$, molybdenite $\left(\mathrm{MoS}_{2}\right)$, and tungstenite $\left(\mathrm{WS}_{2}\right)$. The result of thiosulfide oxidation generated $\mathrm{H}^{+}$(or sulfuric acid) that dissolute metal in mining waste. So, the bacteria involving in this process are important members of microbial consortia used to recover copper, zinc, lead, niken, gold, etc. via bioleaching (Valdés et al., 2008)(Olson et al., 1990).

In our study, we have conducted the sampling campaign to isolate the key players in bioleaching process in abandoned Tin mining area, at Ha Thuong commune, Thai Nguyen province. Our aims of this study were to isolate acidophilic bacteria and characterize their growth properties, which will be the underlining knowledge for further applications in mining or electronic wastes treatment.

\section{Materials and method}

\subsection{Sampling sites}

The total of 5 samples was collected from Ha Thuong tin mine (Latitude 105॰41'427', E, Longitude 21॰38'015' $\mathrm{N}$ ). Among five samples, there are two soil samples from fernfarming, tailing and mining soils, one sludge sample from the wastewater pond, and two water samples from the wastewater pond and canal (table 1).

\subsection{Isolation and identification of acidophilic bacteria}

\subsubsection{Isolation of acidophilic bacteria}

The collected samples were enriched in mineral medium. The component of the mineral medium included $\mathrm{KH}_{2} \mathrm{PO}_{4}$ : $3 \mathrm{~g} / \mathrm{L}, \quad \mathrm{MgSO}_{4} .7 \mathrm{H}_{2} \mathrm{O}: 0.5 \mathrm{~g} / \mathrm{L}, \quad\left(\mathrm{NH}_{4}\right)_{2} \mathrm{SO}_{4}: 3 \mathrm{~g} / \mathrm{L}$, $\mathrm{CaCl}_{2} .2 \mathrm{H}_{2} \mathrm{O}: 0.25 \mathrm{~g} / \mathrm{L}, \mathrm{Na}_{2} \mathrm{~S}_{2} \mathrm{O}_{3} .5 \mathrm{H}_{2} \mathrm{O}: 5 \mathrm{~g} / \mathrm{L}$ with the $\mathrm{pH}$ value adjusted to $\mathrm{pH} 4.4 \sim 4.7$ by $\mathrm{H}_{2} \mathrm{SO}_{4} 10 \mathrm{~N}$. After seven days of enrichment at $30^{\circ} \mathrm{C}$, the samples were transferred into new flasks of the mineral medium and incubated at $30^{\circ} \mathrm{C}$ for 7 days without shaking. The enrichment protocol was repeated three times, and the presence of acidophilic bacteria in liquid medium was detected via the lowering of $\mathrm{pH}$ value, approximately $\mathrm{pH}$ of 2 or 3 . The acidophilic bacteria were isolated by spreading enriched liquid medium to petri disk of the mineral medium agar. The colonies of bacteria on each petri disk were picked up and isolated.

\subsubsection{Identification of acidophilic bacteria}

Morphological identification: The isolated bacteria culture was collected by centrifugation at $6000 \mathrm{x} \mathrm{g}$ and washed four times by deionized water. Cell culture was stained by Gram's stain for identification (Manual of Clinical Microbiology 3ed) and observed at optical microscopy at $1000 \mathrm{x}$ magnification (with oil).

Extraction and purification of bacterial genomic DNA: The bacterial cells harvested by centrifugation at $9000 \mathrm{x}$ g were washed with deionized water. The total genomic DNA was purified by using Biobasic Canada kit. The total DNA was dissolved in $100 \mu 110 \mathrm{mM}$ Tris $\mathrm{HCl} \mathrm{pH} 8.0$ and stored at $4^{\circ} \mathrm{C}$.

PCR amplification and sequencing of $16 \mathrm{~S}$ rDNA gene: PCR amplification of the 16S rDNA gene was carried out to generate approximately a $1.5 \mathrm{~Kb}$ band on the electrophoresis using the forward primer FD1 (5' AGAGTTTGACCTGGCTCAC - 3') and the reverse primer RP2 (5' - CGGCTACCTTGTTACGACTT - 3'). The PCR amplification was carried out with $25 \mu$ of $2 \mathrm{X}$ Taq PCR Mastermix, $2 \mu 1$ of $5 \mathrm{nM}$ each of primers, purified DNA genome $20 \mathrm{ng} / \mu \mathrm{l}$, and the reaction mixture made to a final volume $50 \mu \mathrm{l}$ with deionised water in Mastercycler personal (Eppendorf, Germany). The conditions used for PCR were as following: predenaturation at $95^{\circ} \mathrm{C}$ for $2 \mathrm{~min}$, followed by denaturation at $95^{\circ} \mathrm{C}$ for 25 seconds, annealing at $54^{\circ} \mathrm{C}$ for $1 \mathrm{~min}$, and extension at $72^{\circ} \mathrm{C}$ for 70 seconds, in which thermal cycling was 35 cycles. Gel electrophoresis was used to test the PCR products by $1.2 \%$ dyed with Ethidium bromine agarose gel, the band was observed at $\lambda$ 320nm. The product band was cut and purified by Quiaquick gel axtraction kit (Quiagen, Germany). The purified 16S rDNA was sequenced by Macrogen Inc (Korea) with the same forward and reverse primers in PCR. The obtained sequences were analyzed and aligned with other published sequences from Genbank by software Mega 6.06.

\subsection{Growth conditions of isolated bacteria}

\subsection{1 $\mathrm{pH}$ condition}

The isolated bacteria were cultured in $250 \mathrm{ml}$ flaks containing $200 \mathrm{ml}$ mineral medium at $\mathrm{pH}: 2,4$ and 6 at room temperature $\left(27^{\circ} \mathrm{C}\right)$. The bacterial growth was monitored by sampling $5 \mathrm{ml}$ of cultures everyday and measuring the optical density at the wavelength of $600 \mathrm{~nm}$.

Table 1. Metal concentrations and $\mathrm{pH}$ values in the sampling sites 


\begin{tabular}{cccccccc} 
No & Label & $\begin{array}{c}\text { Type of } \\
\text { samples }\end{array}$ & $\mathbf{p H}$ & $\mathbf{Z n}(\mathbf{p p m})$ & $\mathbf{P b}(\mathbf{p p m})$ & $\mathbf{C d}(\mathbf{p p m})$ & $\mathbf{C u}(\mathbf{p p m})$ \\
\hline 1 & DBDX-HT & Soil & 3.64 & 120.7 & 213.5 & 0.16 & 364 \\
2 & BCHC-HT & Sludge & 3.15 & 99.9 & 384.5 & 0.25 & 1172.9 \\
3 & DHP-HT & Soil & 2.61 & 107 & 135.5 & 0.2 & 357.8 \\
4 & NHC-HT & Water & 2.8 & 2.796 & 0.134 & 0.0019 & 14.88 \\
5 & NKT-HT & Water & 2.91 & 7.217 & 0.626 & 0.0062 & 13.771 \\
\hline
\end{tabular}

\subsubsection{Temperature condition}

The isolated bacteria were cultured in $250 \mathrm{ml}$ flaks containing $200 \mathrm{ml}$ mineral medium at temperatures: $25^{\circ} \mathrm{C}, 30^{\circ} \mathrm{C}$, $35^{\circ} \mathrm{C}, 40^{\circ} \mathrm{C}$. The bacterial growth was monitored by sampling $5 \mathrm{ml}$ of cultures everyday and measuring the optical density at the wavelength of $600 \mathrm{~nm}$.

\section{Results and discussion}

\subsection{Isolation and identification of acidophilic bacteria}

After enrichment cultures, two strains of acidophilic bacteria was isolated from DBDX and NKT samples. The Gram's stain showed that two isolates (DBDX and NKT) belong to two different groups, the DBDX isolate was Gram-positive, other of NKT sample was Gram-negative (Figure 1). Although the image obtained at 1000 magnification in figure 1 are not clear enough to clarify whether the isolate from DBDX sample is spherical or rod shape, the isolate from NKT sample is rod shape.
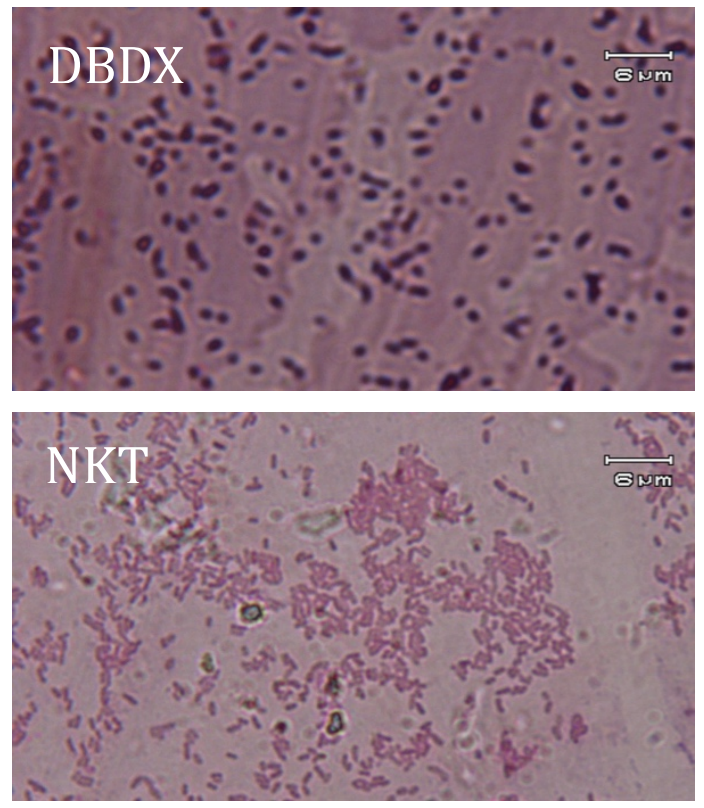

Figure 1. Images of Gram's stain isolates at optical microscopy
PCR products of NKT and DBDX isolates were checked by electrophoresis (Figure 2). The bands of $16 \mathrm{~S}$ rDNA appeared at approximately $1.5 \mathrm{~Kb}$ as expected. The sequences of two isolates were used to construct the dendrogram with other similar sequences retrieved from GenBank (Figure 3 ). Based on the phylogenetic tree, two isolates are distinguished from each other. The strain DBDX is identical to that of the Acidithiobacillus ferrooxidans (98\%) and the nucleotide sequences of $16 \mathrm{~S}$ rDNA from NKT isolate was identical to that of the Acidithiobacillus thiooxidans (94\%) from Genbank. The sequencing results confirmed the Gram's staining of the cells because $A$. ferrooxidans and $A$. thiooxidans are Gram-positive and negative bacteria, respectively. The two bacteria are phylogenetically different.

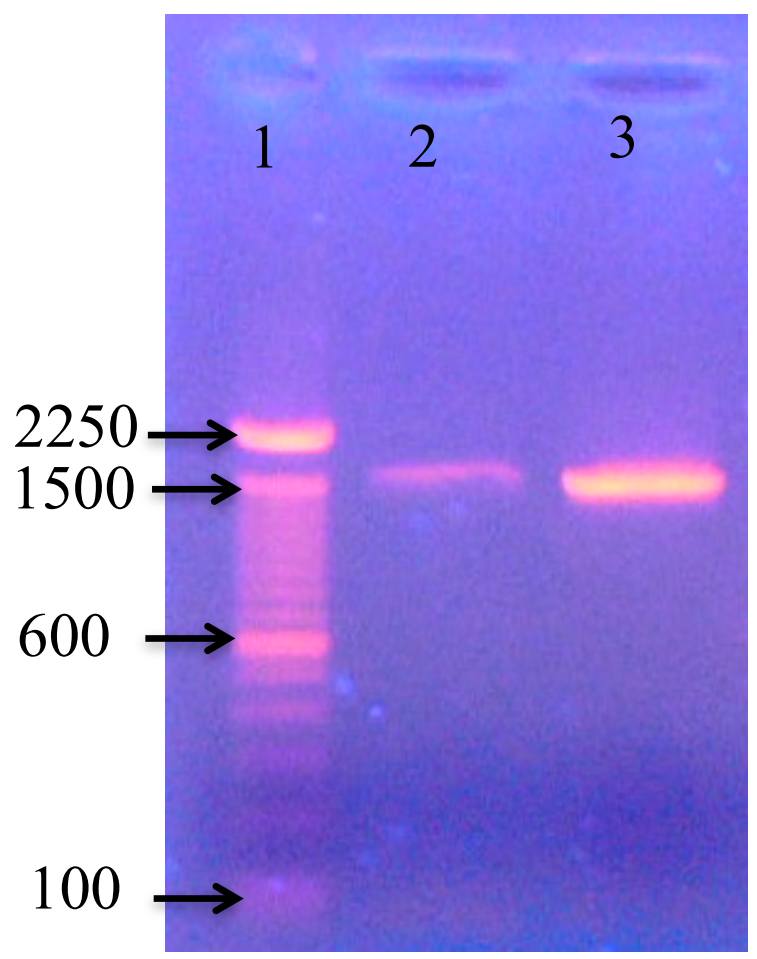

Figure 2. The image from the electrophoresis of the $16 \mathrm{~S}$ rDNA PCR amplification, 1: NKT and 2: DBDX 


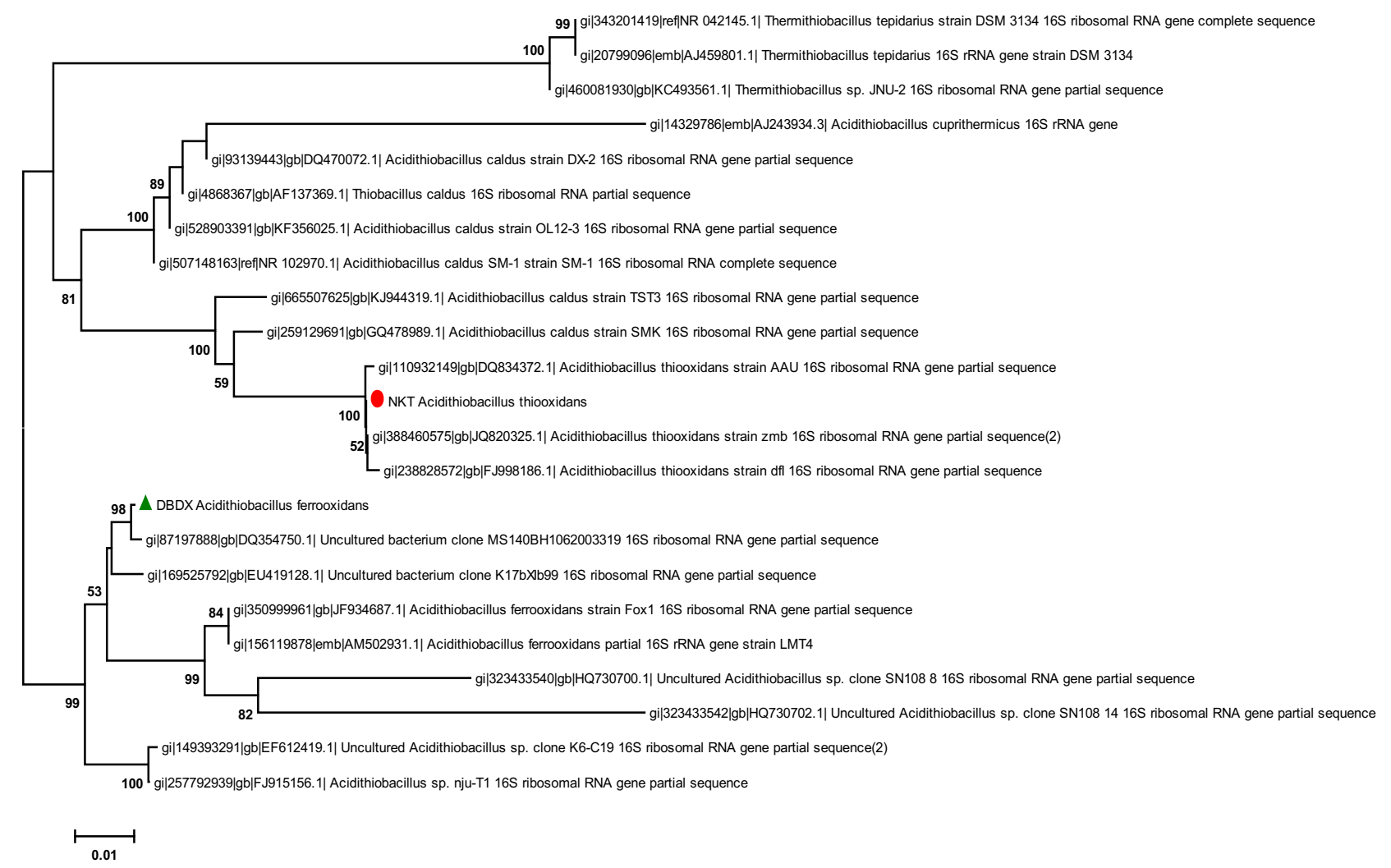

Figure 3. Phylogenetic tree of two strains (NKT and DBDX) based on the sequences of 16S rDNA

\subsection{Effect of $\mathrm{pH}$ values on the growth of two strains}

Figure 4 showed that the optimal $\mathrm{pH}$ value for the growth of two isolated strains was at $\mathrm{pH} 4$ after five day incubation at room temperature. The growth of both strains was low at $\mathrm{pH} 2$ and 6 . The data on the figure 4 also demonstrated that the NKT strain was more sensitive to high $\mathrm{pH}$ value than the DBDX strain. The growth curves of two isolates also supported that the DBDX strain biomass (optical density (OD)) still increased at day 6 whereas the NKT strain had a biomass decrease (data not showed).

It is interesting that the two strains grew slowly at low $\mathrm{pH}$ ( $\mathrm{pH}$ 2) while the acidophilic bacteria can perform bioleaching of metals best at $\mathrm{pH}$ lower than 2 (Zhou et al., 2007)(Bayat et al., 2009)(Gao et al., 2007). Zhou et al. (2007) reported the isolate from coal heap drainage grew optimally at initial $\mathrm{pH} 2$ and its 16S rDNA gene sequence was more than $99 \%$ similar to Acidithiobacillus caldus. When isolating acidophiclic bacteria from an extreme acid drainage mine site, Gao et al., (2007) found and identified a strain of Leptospirillum ferriphilum that has an optimal growth at the $\mathrm{pH}$ of 1.6. In addition, the bacteria Acidithiobacillus ferrooxidans can leach $\mathrm{Zn}$ at maximum rate at the $\mathrm{pH}$ of 1.3. Our two strains were isolated from the samples with the $\mathrm{pH}$ around 3 (table 1 ), thereby adapting to the $\mathrm{pH}$ of 3 , however, the $\mathrm{pH}$ of medium can reach at the $\mathrm{pH}$ of 2 after seven days of incubation.

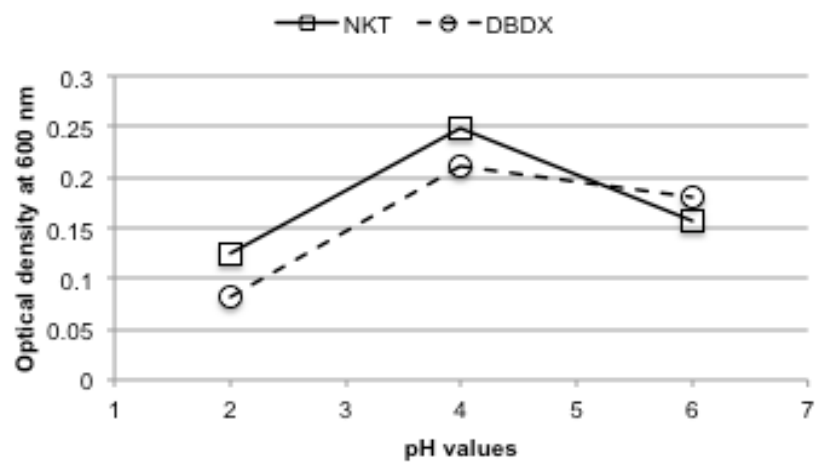

Figure 4. The effect of $\mathrm{pH}$ on the OD of two strains at different $\mathrm{pH}$ values at after five day incubation

\subsection{Effect of temperature on the growth of two strains}

Two strains of isolated acidophilic bacteria were inoculated in the mineral medium and incubated at different temperatures, ranging from 25 to $40^{\circ} \mathrm{C}$. Figure 5 demonstrated the result of the growth of two strains after five day incubation. The result clearly pointed out that two strains are not tolerant to high temperature, the optimum temperature is around $30^{\circ} \mathrm{C}$. 


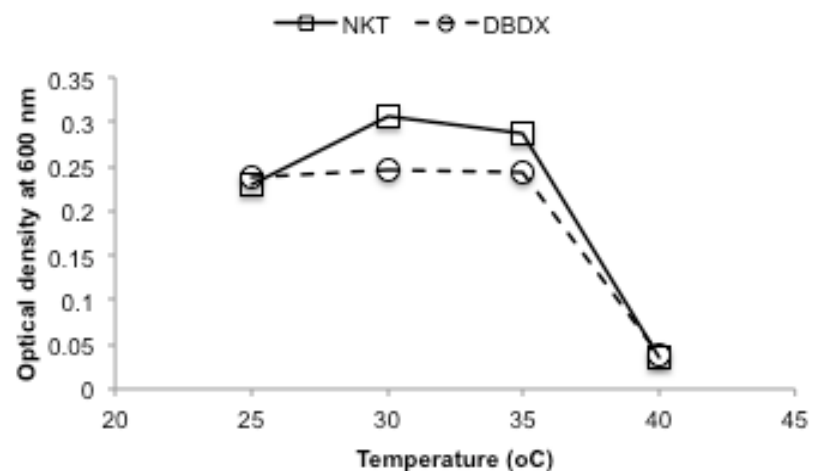

Figure 5. The effect of temperature on the OD of two isolated strains growing at different temperatures after five days of incubation

Hallberg et al. (2011) investigated in a comprehensive physiological and phylogenetic characterization of Acidiferrobacter thiooxydans, an acidophilic, thermo-tolerant, facultatively anaerobic iron- and sulfur-oxidizer of the family Ectothiorhodospiraceae and reported the optimal temperature for this bacteria was $38^{\circ} \mathrm{C}$ and the maxiumal tolerance temperature was $47^{\circ} \mathrm{C}$. However, the bioleaching of $\mathrm{Zn}$ by Acidithiobacillus ferrooxidans was normally carried out at the temperature of $30^{\circ} \mathrm{C}$ (Bayat et al., 2009).

\section{Conclusions}

The isolation of acidophilic bacteria was successful with two new strains NKT and DBDX, the NKT strain can be identified as Acidithiobacillus sp. and the DBDX strain as Acidithiobacillus ferrooxidans. Both strains possess the different physiological properties in comparison with other Acidithiobacillus bacteria, low tolerance to temperature and $\mathrm{pH}$ values, implying the new species.

\section{Acknowledgement}

This research is funded by the Vietnam National Foundation for Science and Technology Development (NAFOSTED) under grant number 106.16-2011.65 and the program "Young scientist's fund" from Vietnam Academy of Science and Technology.

\section{References}

[1] Bayat, O., Sever, E., Bayat, B., Arslan, V., Poole, C., 2009. Bioleaching of zinc and iron from steel plant waste using Acidithiobacillus ferrooxidans. Appl.
Biochem. Biotechnol.152(1).117-126.

[2] Gao, J., Zhang, C.G., Wu, X.L., Wang, H.H., Qiu, G.Z., 2007. Isolation and identification of a strain of Leptospirillum ferriphilum from an extreme acid mine drainage site. Ann. Microbiol. 57(2).171-176.

[3] Olson, G.J., Sakai, C.K., Parks, E.J., Brinckman, F.E., 1990. Bioleaching of cobalt from smelter wastes by Thiobacillus ferrooxidans. J. Indutr. Microbiol. 6. 49-52.

[4] Rzhepishevska, O.I., Valdes, J., Marcinkeviciene, L., Gallardo, C.A., Meskys, R., Bonnefoy, V., Holmes, D.S, Dopson, M., 2007. Regulation of a novel Acidithiobacillus caldus gene cluster involved in metabolism of reduced inorganic sulfur compounds. Appl. Environ. Microbiol. 73(22). 7367-7372

[5] Sharma, A., Kawarabayasi, Y., Satyanarayana, T., 2012. Acidophilic bacteria and archaea: acid stable biocatalysts and their potential applications. Extremophiles.16(1).1-19.

[6] Sugio, T., Wakabayashi, M., Kanao, T., Takeuchi, F., 2008. Isolation and characterization of Acidithiobacillus ferrooxidans strain D3-2 active in copper bioleaching from a copper mine in Chile. Biosci. Biotechnol. Biochem. 72(4). 998-1004.

[7] Valdés, J., Pedroso, I., Quatrini, R., Dodson, R.J., Tettelin, H., Blake, R., et al., 2008. Acidithiobacillus ferrooxidans metabolism: from genome sequence to industrial applications. BMC Genomics. 9. 597.

[8] Wang, J., Bai, J., Xu, J., Liang, B., 2009. Bioleaching of metals from printed wire boards by Acidithiobacillus ferrooxidans and Acidithiobacillus thiooxidans and their mixture. J. Hazard. Mater. 172(2-3).1100-1105.

[9] Willner, J., 2012. Leaching of selected heavy metals from electronic waste in the presence of the $A$. ferrooxidans bacteria. 55(2). 860-863.

[10] Willner, J., Fornalczyk, A., 2013. Extraction of metals from electronic waste by bacterial leaching. Environ. Prot. Eng. 39(10). 197-208.

[11] Zhou, Q.G., Bo, F., Hong, B.Z., Xi, L., Jian, G., Fei, F.L., et al., 2007. Isolation of a strain of Acidithiobacillus caldus and its role in bioleaching of chalcopyrite. World J. Microbiol. Biotechnol. 23(9). 1217-1225. 